\title{
Navigating Ethical Dilemmas in Mental Health Practice Between Professional Ethics and Islamic Values
}

\author{
Khalid Elzamzamy \\ Hamad Medical Corporation \\ Hooman Keshavarzi \\ Khalil Center/Ibn Haldun University
}

\begin{abstract}
Religiously committed mental health practitioners frequently encounter situations in which their perceived or actual religious mandates are at odds with their client's values, leaving them in an ethical conundrum as to how to reconcile these values with the mandates of their professional ethical codes of conduct. Examples of such conflicts include dealing with cases involving abortion, sexual orientation, gender identity, consensual extramarital affairs, substance and alcohol use, as well as working with clients who display a minimal adherence to basic Islamic rituals and tenets. Precedents to such conflicts have led to serious legal consequences in some cases (DeSantis, 2012; Keeton v. Anderson-Wiley, 2010). Such conflicts are commonplace and particularly important for Muslim mental health professionals operating in the United States and other Western European countries that have secular professional codes of ethics. This paper is a "narrative literature review" that attempts to frame the discussion about value conflicts commonly experienced by Muslim mental health clinicians working within the Islamic legal and ethical discourses in the American context. This is done by analyzing the origins of some of these conflicts as well as providing potential resolutions. First, the relevant mental health philosophies, principles, codes, and definitions are examined. Second, the authors highlight how the Islamic maqāșid (the higher objectives of Islamic law) and $u s \underline{u} l$ (legal maxims), as well as Islamic standard practices, morals, and professional ethics, appear to contribute to the ethical dilemma. Different approaches to conflict resolution and reconciliation between Islamic mandates and ethical dilemmas are presented to help clinicians navigate their professional practice within ethical guidelines while remaining faithful to their religious values.
\end{abstract}




\section{Case Scenario}

Hussain is a 27-year-old man who has experienced same-sex attraction since he was a teenager. He describes himself as an adherent of Islam and subscribes to the belief that homosexual behavior is sinful, religiously illicit, and immoral. He came to a Muslim therapist for help in resolving the conflict he was experiencing with his family, who rejects his sexual orientation and behavior. Hussain reported struggling with feelings of guilt in addition to feeling alienated and abandoned by his family. However, he stated that he cannot imagine giving up his same-sex lifestyle due to his belief that his sexual preferences are not volitional and that he was given no choice in terms of being created this way. Despite this conflict between his religious values and his proclaimed sexual orientation, Hussain said that he performs his five daily prayers and self-identifies closely with Islam.

\section{Introduction}

Hussain's case represents a common myriad of issues that arise in clinical settings, particularly mental health settings, when a clinician's personal values conflict with either the client's values or the code of ethics that regulates their professional practice. This case also highlights the interplay between spirituality/religion and mental health.

Religiously committed clinicians and therapists frequently encounter situations similar to the one highlighted above. As a result, they often find themselves forced to make ethical choices in an attempt to reconcile their personal religious values and beliefs with professional ethical guidelines and expectations. Such conflicts could have serious consequences in countries where the legal system plays a strong role in supervising the implementation of such guidelines. Take, for example, the famous case of Julea Ward, a conservative Christian who was attending Eastern Michigan University as a counseling trainee. Her ethicsbased refusal to counsel a client on his same-sex relationship led to many years of litigation, after which she was dismissed from the program on the grounds that her choice violated the American Counseling Association's (ACA) Code of Ethics that "counselors may not discriminate against clients on the basis of age, culture, disability, ethnicity, race, religion/spirituality, gender, gender identity, sexual orientation, marital status/partnership, language preference, socioeconomic status or any basis proscribed by law" (Rudow, 2013). This case is just one of many in which the court had to be involved to enforce the code of ethics in such cases, and the resulting consequences were harsh (DeSantis, 2012; Keeton v. AndersonWiley, 2010).

The ACA Code of Ethics (American Counseling Association [ACA], 2005) further states that counselors are expected to be aware of their own values 
and "avoid imposing values that are inconsistent with counseling goals" (Standard A.4.b.). A significant amount of controversy also surrounds value-based referrals that hinge on whether the "inability to be of professional assistance" in Standard A.11.b only applies to issues of competence or to value-based referrals as well. Consensus seems to have been reached on competence-based referrals when the offered treatment lies outside the counselor's competence (Remley \& Herlihy, 2010). Thus, some clinicians find themselves in an ethical conundrum: Imposing their values on patients would clearly violate their personal ethical principles, and the alternative of making value-based referrals could render them liable for refusing to provide services for potentially discriminatory reasons.

Some could argue that such conflicts are particularly important for Muslim mental health professionals operating in non-Muslim countries that follow secular codes of ethics. This is a plausible argument, given the underdeveloped mental health services let alone lack of organized professional bodies and codes of ethics, in many Arab and Muslim countries (Al-Krenawi, 2005; Okasha, Karam, \& Okasha, 2012). However, many of these same professionals working in Muslimmajority countries were trained in schools, universities, and hospitals that wholeheartedly adopt Western secular systems of education, practice, training, and standards of practice. Even though such codes of ethics might not be enforced in Muslim-majority countries, they are still considered the reference point for such professionals because they often inform the professionals' understanding of their scope, limitations, and role of professional practice.

Value and ethical conflicts are not unique to religious clinicians, for they can emerge in different forms in medical and mental health settings. As Kocet and Herlihy (2014) put it, "counselors must be aware that clients may bring up, at almost any time and in any context, topics that push the counselor's personal 'buttons"' (p. 183). For example,

(a) a Catholic counselor and a client considering an abortion, (b) a Mormon counselor and a client whose lifestyle includes smoking cigarettes and drinking alcohol, (c) a devoutly religious counselor and an atheist client, (d) a Jewish counselor and a bigoted client who uses offensive and anti-Semitic language to describe Jews, (e) a self-identified liberal or progressive counselor and an evangelical Christian client, and (f) a feminist counselor and a client who is an exotic dancer at a gentlemen's club. (p. 183)

Frequently reported conflicts faced by religious clinicians include cases of abortion, same-sex orientation, gender identity problems, extramarital sexual relations, substance and alcohol use, as well as clients who report being loosely 
adherent to basic Islamic rituals and tenets, such as the obligatory daily prayers and the Ramadan fast.

Under pressure from such value conflicts, clinicians find themselves forced to make ethical choices, such as (a) accepting or refusing to work with a certain client, (b) referring a client to a different therapist, (c) self-disclosing their own values, and (d) imposing or bracketing their personal values.

The last few decades have witnessed a plethora of literature addressing these value conflicts and ethical dilemmas. However, most of it addresses general personal value conflicts in various mental health fields (Elliot, 2011; Stewart, 2009; Shallcross, 2010, Allen, 2012; Kocet \& Herlihy, 2014; Grimm, 1994, Carlson \& Erickson, 1999; Hathaway \& Ripley, 2009). Some literature focuses on the experiences of clinicians from certain faith backgrounds, such as Christianity (Scott 2011; Lopes de Jesus, 2016; Morrison \& Borgen, 2010).

Very few publications have touched upon Islam or being Muslim as potential contributors to value conflicts in clinical settings. In their study on the intersection of faith, sexual orientation, and gender, Balkin, Watts, and Ali (2014) presented a general overview of the three main Abrahamic faiths' views on sexuality and gender and their role in potentially raising ethical dilemmas in clinical settings.

Patel and Shikongo (2006) interviewed five Muslim psychology students about their understanding of spirituality and its perceived role in therapy as trainees in a secular training program, and Al-Rabae (2009) analyzed different aspects of what it means for Muslim clinicians to operate under "Western" codes of ethics. After dissecting the roots of "Western" counseling philosophy and codes of ethics, Al-Rabae attributed their emergence to secular movements in the West. Although secular and Islamic worldviews are in essence incompatible, he highlighted some commonalities between Islamic morals and secular codes of ethics. But despite his lengthy account on the roots of this particular conflict, he provided scant guidance on how a Muslim counselor can solve these potential ethical dilemmas and value conflicts.

This paper attempts to dissect the nature of the ethical dilemmas commonly experienced by some Muslim mental health practitioners. The authors will shed light on the nature and context of these value conflicts and seek to unpack the origins and foundation of the ensuing tension. They first examine those aspects of the various secular mental health philosophies, principles, and codes considered potentially problematic for the religiously observant and serve as the sources of the perceived or actual conflict with Islamic ethics. Second, they highlight how Islam's ethical worldview, principles, beliefs, morals, and ethics contribute to the dilemma. In their analysis of Islamic ethics, the authors rely on the scholarly works of Sunni theologians ('ilm al-kalām), Islamic jurisprudence (fiqh), and Muslim physicians from the early medieval period prior to the modern 
era of industrialization and the secularization of medicine. Such perspectives provide the relevant authoritative literature that informs Islamic ethics and will orient readers toward an appreciation of the foundations and flexibility of Islamic ethics. Finally, different approaches to conflict resolution are presented and analyzed as potential ways forward.

\section{Terminology}

At this point, certain key terms and concepts frequently referenced in ethics literature and used throughout this paper need to be qualified. When referring to value conflicts in clinical settings, a "value" could be defined as "conceptions of the desirable that guide the way persons select actions, evaluate people and events, and explain their actions and evaluations... Values express what people believe to be good or bad, and what they think should or should not be done" (Roccas, 2005). "Value conflict" refers to either a clinician-client conflict over personal values or a conflict between personal and professional ethical values. "Personal values" could "stem from cultural, religious, moral, or personal belief, life experience, or a potential countertransference issue," while "professional conflicts" could stem from lack of proper training or skill in a particular area of practice (Kocet \& Herlihy, 2014).

Accordingly, Allen (2012) stated that a situation could be called an "ethical dilemma" if three conditions are met: (a) a decision must be made about the best course of action, (b) different courses of action must be available, and (c) any action taken will compromise some ethical principle. In short, no ethical dilemma has a perfect solution and a dilemma exists only in the absence of different courses of action.

"Codes of ethics" (COE) are a set of standards and principles of morally right professional conduct that is accepted and considered appropriate to a specific field (VandenBos, 2013, pp. 114, 216). "Standards of practice" (SOP) refer to a set of guidelines that delineate the appropriate interventions to be utilized with individuals experiencing different conditions. They are designed to ensure that clinicians use the most researched and validated interventions and therapies (VandenBos, 2013, p. 558).

\section{Secular Mental Health Ethical Codes and Values}

Most medical and mental health codes of ethics include some universal principles. Take, for example, the American Psychological Association's (APA) "Ethical Principles of Psychologists and Code of Conduct" (2017), which is considered one of the major ethical codes in American practice. This code lists five principles: "1. Beneficence and Nonmaleficence, 2. Fidelity and Responsibility, 3. 
Integrity, 4. Justice, 5. Respect for People's Rights and Dignity" (pp. 3-4) - all of which converge with many Islamic principles and values. However, due to their general nature, their practicality in terms of addressing more specific value conflicts is very limited.

Additionally, constructing an ethical code originates from how the common good is understood. Even though some Muslim theologians, such as the Maturidis (the Māturīdiyya is a Sunni theological school of thought adopted by the majority of Hanafi jurists), would agree on the notion of universally acceptable ethics and values, this often becomes more obscured when greater specificity is involved (al-Taftāzān̄̄, 2000), for one can argue that each universal principle can be invoked to support varying and at times conflicting viewpoints, especially when facing ethical dilemmas.

Although the COE and SOP delineate more specific and operational guidelines, ethical dilemmas sometimes raise questions about their clarity. In addition, the perspectives of both expert clinicians as well as mental health students have indicated the existence of frequent confusion and conflicts when it comes to interpreting and applying certain problematic ethical codes (Burkholder et al., 2014; Burkholder \& Hall, 2014).

One of the most critical codes of ethics that is frequently invoked in ethical dilemmas is code A.4.b. titled "Personal Values," which states that

Counselors are aware of - and avoid imposing - their own values, attitudes, beliefs, and behaviors. Counselors respect the diversity of clients, trainees, and research participants and seek training in areas in which they are at risk of imposing their values onto clients, especially when the counselor's values are inconsistent with the client's goals or are discriminatory in nature." (ACA, 2014, p. 5)

As Elliott (2003) explained, such codes exist to safeguard against any clinician's potential abuse of power, given the nature of the therapeutic relationship.

In addition, code "C.2.a. Boundaries of Competence" states

Counselors practice only within the boundaries of their competence, based on their education, training, supervised experience, state and national professional credentials, and appropriate professional experience. Whereas multicultural counseling competency is required across all counseling specialties, counselors gain knowledge, personal awareness, sensitivity, dispositions, and skills pertinent to being a culturally 
competent counselor in working with a diverse client population. (ACA, 2014, p. 8)

Clinicians who refuse to work with gay clients and refer them to other clinicians frequently invoke this problematic statement to support their action. However, others have argued that it should not be the base for such referrals; rather, clinicians should seek training to become competent enough to meet their clients' needs instead of using their lack of competence to justify such decisions (Elliott, 2011; Shallcross, 2010).

In other words, "The issue of competence cannot be used as an excuse to engage in discrimination" (Martz \& Kaplan, 2014). This is based on the ACA's "C.5. Nondiscrimination" code, which states

Counselors do not condone or engage in discrimination against prospective or current clients, students, employees, supervisees, or research participants based on age, culture, disability, ethnicity, race, religion/spirituality, gender, gender identity, sexual orientation, marital/ partnership status, language preference, socioeconomic status, immigration status, or any basis proscribed by law. (ACA, 2014, p. 9)

Therefore, clinicians are expected not to make referrals based on personal values related to the characteristics listed in the above code, but to put their clients' needs above their personal values (Elliott, 2011). Clinicians, by the inherent qualities of their profession, are supposed to enhance their client's wellbeing instead of re-exposing them to the discrimination they typically experience in other settings.

\section{Competing Scopes of Practice}

Considerations for devising more specific guidelines for ethical practice ultimately relates to the mental health practitioner's conceptualization of their role and scope of practice. Those who adhere to the general secular practice of healthcare generally understand that their scope is limited to alleviating pathology while demonstrating sensitivity to the patient's cultural context. This separation might be much clearer when dealing with physical disorders, for in such cases the patient's personal values emerge less often. However, mental health practitioners find this challenge more complicated because the patient's religious and cultural values and beliefs cannot be so easily separated from the expressions of psychopathology that are often intertwined with his or her personal worldviews and identity. 
This is due to the fact that psychotherapy exists to modify the patient's worldview, beliefs, and behaviors. For example, Cognitive Behavioral Therapy (CBT), a dominant psychotherapeutic modality, focuses on modifying pathological beliefs which are considered irrational and which maintain psychological symptoms. Religion also qualifies acceptable and pathological beliefs and behaviors, albeit through a different epistemological framework. Thus, there can be a conflict over how "pathology" is defined or determined and the practitioner's associated responsibility in a secular versus religiously oriented construction of health. In the context of a secular behavioral science, as defined by the Diagnostic and Statistical Manual of Mental Disorders (DSM-5), those pathological beliefs and behaviors clearly cause dysfunction in one or more of the categories of family, social, and occupational life (APA, 2013, p. 20).

Given the element of social convention and constructivism in classifying mental disorders, the DSM has undergone many changes since its initial publication in 1952. In fact, significant re-classifications and de-classifications have been made of some mental disorders that are consistent with the changing sociopolitical attitudes in the U.S. and Western Europe, such as removing homosexuality from the DSM in 1973. This places certain religiously sanctioned behaviors that could be the subject of psychotherapeutic interventions beyond the scope of a largely secular mental health profession. An Islamic theological lens on the practitioner's scope of practice, however, necessarily includes considering the adverse effects of spiritual pathologies that extend beyond the DMS's three listed domains, for these effects may cause harm in the afterlife. Thus, spiritual pathologies may be seen as extensions of psychopathology.

As a result of this reality, the process of issuing Islamic legal dispensations or disability accommodations for specific patients requires the opinions of morally upright ( $a d l$ ) Muslim experts, given the expectation that their recommendations would balance psychological and physical distress in the temporal life with the implications of healthcare decision making in the afterlife (Keshavarzi \& Ali, 2018b). Although the "do no harm" principle is shared by the Islamic legal maxim that "harm shall not be inflicted nor reciprocated," the potential point of divergence here is whether this role extends beyond psychopathology or the individual to the community and society at large (Sachedina, 2009, pp. 12-13).

Additional complications may arise when the treatment's very nature conflicts with the practitioner's perceived role. For example, Al-Ghazālī narrated a tradition that asserts that those who assist in sin (even by half a word) are partners in it (Al-Ghazālī, 1993, p. 1). Thus, when Muslim practitioners are called upon to provide relational therapy to patients involved in a religiously defined illicit relationship (e.g., homosexuality, infidelity, or fornication), they may feel at odds with adhering to the secular professional ethics codes that conflict with their 
religious codes of conduct. However, a clinician's attempt to intervene and modify such behaviors would be potentially imposing their own values on clients and perhaps using practices that are not evidence-based. These are considered infractions according to the ACA code A.4.b. on "Personal Values" mentioned above, as well as code C.7.a. "Scientific Basis for Treatment" which states: "When providing services, counselors use techniques/procedures/modalities that are grounded in theory and/or have an empirical or scientific foundation" (p. 10). Against this backdrop, Malik Badri (1979) argues that Muslim psychologists must be critical of modern psychology drawn from the West and beware of the contradictions it poses to their religion and culture. He views Western psychology as a culture-bound discipline stemming from secular anti-religious roots and therefore largely reductionistic in nature, by which he means that it limits its scope to biological, social, and psychological factors and ignores the soul and spirituality as essential ingredients of human experiences (Kasapovic, 2018). Other Muslim psychologists, among them Skinner and Al-Rabae, seem to agree with him (Al-Rabae, 2009; Kasapovic, 2018).

Moreover, many researchers in the field of cross-cultural psychology have asserted that the current body of psychology as a science does not represent the human experience at large, which argues against the universality of some or many of its components (Arnett, 2008; Cole, 2006; Sue, 1999; Kim, 2000). In that regard, Al-Rabae has argued that "Western" codes of ethics are an extension of the culture and philosophy of the secular-born psychology. Although one can find many commonalities between these "Western" codes and Islamic values and morals, several ethical principles and standards of practice could pose ethical challenges to observant Muslim clinicians.

\section{Islamic Ethics: Theoretical and Practical Perspectives}

\section{The Islamic Ethical Worldview}

The roots of Islam's multi-dimensional ethical worldview draw upon many disciplines, among them theology, jurisprudence, and philosophy (Ramadan, 2018). Thus, the ethical and moral philosophies that underlie Islamic ethics and Muslim practices can vary significantly from those that do not share Islam's unique ontological and epistemological foundations.

While Muslim philosophers and some Islamic sects such as the Mu'tazilites (a rationalist school of Islamic theology) have adopted extensively rational epistemological approaches to ethics, the majority of Sunni Muslim theologians and jurists have relied more heavily on scripture and prophetic traditions (i.e. the Qur'an and Sunna) as the basis informing the core components of faith (Hourani, 2007). 
This heavy emphasis on scripture and faith means that Islamic ethical decision making differs significantly in its foundations from similar efforts made within a secular ethical framework. The authors highlight three core features of the Islamic worldview that diverge significantly from secular codes of conduct: Islamic ethics are largely (a) theistic in origin, (b) metaphysical and transcendental in scope, and (c) community-oriented or collectivistic.

From an ontological perspective, most Sunni theological and legal schools view ethics from a lens of "theistic subjectivism," viewing God and revealed texts as the ultimate source of right and wrong. In other words, this divine command framework is held to provide universal ethical principles for a code of conduct and an Islamic worldview. Any infractions are considered immoral or unethical and viewed as interfering with one's success and salvation in this world and the hereafter. Relatedly, the second core feature of Sunni Islamic ethics considers humanity's metaphysical origins and how worldly decision making impacts one's afterlife - a view that establishes the purpose of Islamic ethics and rulings: the ultimate preservation of people's best interests on Earth and, more importantly, in the hereafter (Sachedina, 2009, pp. 30, 34-35).

Thus, one can say that Islamic ethics considers three stages of life in this regard: humanity's (a) prenatal metaphysical origins with an accompanying predisposed ethical compass to know truth and the common good, (b) postnatal life, which stretches from childhood to death, and (c) post-mortem life, which is a direct consequence of decisions made during the second stage. This insight provides the basis for evaluating ethical decisions from an Islamic perspective.

Finally, Islamic ethics are largely community-oriented and collectivistic in nature, for an individual supposedly cannot attain salvation outside a communityoriented legal/ethical system. Islamic teachings do not see the public and the private as separable spheres of existence with the individual having full control of his or her private life, even if it does not conform to socially and religiously sanctioned norms. On the contrary, Muslims are expected to abide by a communal order based on rights and responsibilities even when enacting their individual autonomy (Ghaly, 2016, p. 31; Sachedina, 2009, p. 13). In terms of constructing the ethics of any practice or profession, this orientation widens the scope of "do no harm" to including the ultimate benefit and minimizing harm to all members of society.

In this section, the authors attempt to dissect and navigate ethical dilemmas within the Islamic ethical worldview and from the ethical perspective of Sunni theologians-jurists. The authors will examine multiple Islamic ethical dimensions that might give rise to Muslim mental health clinicians' value conflicts, utilizing these discussions to later inform the case analysis of "Hussain" listed at the outset. 


\section{A. Historical Account of Muslims' Professional Ethics}

An appreciation of an integrated healthcare system that is more consistent with an Islamic ethical worldview can be observed across history and through the precolonial writings of Muslim physicians. Many Muslim medical pioneers have written treatises on a proper physician's character and moral conduct with patients and society in general. Such treatises include (1) Adab al-Tabib [Ethics of the physician], by Isḥāq al-Ruhāwī (a 9th-century scholar), (2) Akhlāq al-Ṭabīb [Morals of the physician], by Abu Bakr al-Rāzī (d. 925) and (3) Al-Tibb alNabawī [Prophetic medicine], by Abd al-Mālik al-Andalusī (d. 853) (Fadel, 2013). Given the lack of a separate specialization in mental healthcare during these times, mental health (al-țibb al-rūhānī/al-nafs $\bar{a} n \bar{\imath})$ would generally fall under "medical practice" in such treatises.

In his remarkable treatise on the Ethics of the physician, al-Ruhāwi ${ }^{1}$ dedicated the whole first chapter to highlighting the faith, belief, and the personal ethics that a physician must hold, such as believing in the Creator and His magnificent attributes, loving Him, believing in the messengers and prophets, and doing good deeds. He emphasized the role of revelation and prophethood in ascertaining good from evil and highlighted the limited nature of reason/mind in such an endeavor. Al-Ruhāwī paints a picture of a religious physician who holds firm to these ethics and qualities and views his/her spirituality and religiosity as a central ingredient in outlining the ethics of the practice of his/her profession and career (Al-Ruhāwī, 1967; Padela, 2007).

This is clearly a very different view on Islamic ethics than the one found in modern healthcare practice, where the essence of healthcare ethical values is derived from Islamic theology in actualizing the mission of serving God's creation. In fact, pre-colonial Muslim physicians would be motivated to enter medicine due to the numerous prophetic narrations on the value and eternal rewards of alleviating the suffering of others. In some cases, such healthcare practice would be viewed as a communal religious obligation (fard al-kifāya), and hospitals and community healthcare services would be set up and paid for by

1 "Ishaq ibn Ali al-Ruhawi a ninth-century physician who resided under the Islamic caliphate in modern-day Iraq." "He was born a Christian, and there is a question as to whether he fully embracedIslam. His audience, however, was predominantly Muslim and his writings contain a religious overtone." (Padela, 2007). His date of death is unknown. 
charitable endowments and contributions from both the public and the public treasury (Chaleby, 2001; Ragab, 2015).

This emphasis on belief and religiosity informed the advice al-Ruhāwī offered clinicians when facing value conflicts. In his third chapter, titled "On things of which a physician must beware," he presents Galen's (d. c. 210) idea that the physician should not follow the desires and wishes of patients if they were not beneficial to them. He warned physicians of doing so out of fear of the patient or for monetary benefits and emphasized that they should make their fear and awe of God their top priority and concern. After presenting a practical example of abortion, which resonates with the modern bioethical discourse on the topic, he cautions against elective medication-induced abortions out of "claimed" mercy toward the mother. According to him, fear of the Creator and the greater good of the mother and society are the basis for forbidding elective abortions, unless the pregnancy poses significant harm (darar) to the mother.

In Islamic legal (fiqh) and ethical (Islamic bioethics) discourses, this scenario is just one of many similar ethical dilemmas discussed in great detail by jurists while negotiating between medical necessity and those normative ethical guidelines that require the weighing and qualification of potential harm and necessity (d̦äüra) before granting legal dispensations (rukhaș) and accommodations for healthcare practice (Ali \& Keshavarzi, 2018).

Al-Ruhāwī's portrayal provides a good illustration of the potential value conflicts that a clinician may encounter in clinical practice and highlights religion's major role in creating and maintaining value systems. The recent significant interest in exploring the intersection of these Islamic ethical discourses regarding healthcare practice and modern healthcare dilemmas and scenarios has engendered a new subfield referred to as "Islamic bioethics" (Padela, 2007; Ghaly, 2016).

\section{B. The Higher Objectives and Principles of Islamic Law}

The framework of maqāșid al-sharī 'a (the higher objectives of Islamic law) lends a useful tool in providing an overarching schema for understanding broader Islamic values and informing value conflicts.

In his Al-Mustașfā fì 'Ilm al-Ușūl [The essentials of Islamic legal theory), Al-Ghazālī, building upon his teacher al-Juwayn̄̄'s work, proposed five major essential objectives (darürīy $\bar{a} t)$ of the Islamic shari ' $a$ : the preservation of religion $(\operatorname{din})$, life (nafs), intellect ('aql), family/lineage (nasl), and wealth ( $m \bar{a} l)$ (AlGhazālī, 1992, p. 174; Kamali, 2011, p. 27).

Although the development of the maqassid is historically rooted in the disciplines of figh and law and then extended to philosophy and mysticism, they later became an essential component of the emerging field of Islamic ethics. The 
maqāșid framework has also provided a multitude of concepts and values that have shaped Muslims worldview concerning different aspects of life (Ramadan, 2018, pp. 82-86).

Mental health clinicians, more than any other health specialists, come across situations in their encounters with clients that impact a person's religion, life, mental capacity, family, sexuality, and/or financial situation. Sometimes the client's ailment or illness, or even his/her chosen lifestyle, puts one of the five above-mentioned objectives at stake. Take, for example, a patient with severe depression and suicidal ideas. This patient's life, mental capacity, and social functioning are all at stake due to reasons outside of his/her control. On the other hand, a patient who chooses to drink alcohol socially or engage in extramarital sexual activities is, from an Islamic perspective, violating values that seek to preserve the intellect, family, and possibly wealth, even though the person's behavior raises no clinical concern.

In his letter to one of his student physicians, titled Akhlāq al-Tabīb [Morals of the physician], Al-Rāzī emphasized the unique nature of the physician's position, for they are frequently entrusted with patient's secrets that are perhaps unknown to his/her parents and children. Thus, clinicians are made aware of certain patients' attitudes, behaviors, actions, or deeds that could be considered sinful or immoral according to Islamic normativity. Physicians thus bear the ethical responsibility of confidentiality as emphasized by prophetic traditions and legal maxims, of "Gatherings are characterized by trustworthiness" (Sunan Abī Dāwūd: 4869; Musnad Ahmad: 14166).

This trust entails the responsibility of preserving the patient's right to confidentiality, which is consistent with contemporary mental health practice. However, legal necessity ( darüra) can be cited as an Islamically legitimate excuse and even responsibility to break confidentiality, for confidentiality is not solely limited to imminent threat to a patient's own life or others but also if, in the clinician's judgment, doing so would better serve the patient's overall interests (Bint Abdur Rahman, 2018). An example of this could be any non-consensual disclosures that the practitioner felt would further the patient's treatment, such as involving the imam in order to develop a collaborative care approach, which is clearly at odds with contemporary ethics' practice of limiting disclosure to harming oneself or others.

This difference between a collectivistic Islamic ethical code and a postindustrial individualist conception of harm and benefit to the patient has one significant result: It allows the practitioner to consider harm and benefit both to the patient, their community and greater society as a whole, by exercising their judgment, which is guided by Islamic ideals, while navigating ethical dilemmas that might not be addressed or may at times conflict with mainstream mental health practice. 


\section{Standard of Practice: "al-Amr wa al-Nahy"}

Islamic religious practice is collectivistic in nature and generally aspires for all members of society to maintain social order. Rectifying violations of this order and preserving the five aforementioned objectives (maqāssid) are seen as communal obligations and mandate the principle of al-amr bi al-ma 'rüf wa alnahy 'an al-munkar' (enjoining good and forbidding evil). All Muslims are obliged to uphold this principle and preserve orderly conduct, both personally and communally (Al-Umar, 2017; Al-Munajjid, 2013).

This principle has many roots in the Islamic scriptures, including Qur'anic verses and hadith reports (Qur'an 3:104, 7:165, and 11:116). It was narrated on the authority of $\mathrm{Abu} \mathrm{Sa}{ }^{‘} \bar{i} d$ al-Khudrī, who said,

I heard the messenger of Allah, peace be upon him, say, "Whosoever of you sees an evil, let him change it with his hand; and if he is not able to do so, then with his tongue; and if he is not able to do so, then with his heart - and that is the weakest of faith. (Sahịh Muslim, Book 1, Section 20, Hadith 78).

This hadith establishes what can be viewed as an Islamic "standard of practice" in modern terms. Scholars from different scholarly disciplines have explained this hadith extensively, highlighting its ramifications in the given discipline (Ibn Abī Al-Dunyā, 1997; Ibn Taymiyya, 1983; Rutherford, 2006; Cook, 2001; Farook, 2008; Izadi, Ebrazeh, Drikvand, \& Pouladchang, 2014). On its most personal level, it stratifies the standard practice of a Muslim faced with something deemed munkar (evil) into three levels/approaches: changing the evil with one's hand (physical), changing it with one's tongue (speech), and rejecting it with one's heart (cognitive disapproval).

According to the hadith, the decision to utilize a given approach is based on a person's capability and capacity to change the evil. The third approach is the last and least ideal resort of a faithful person (Ibn Taymiyya, 1983, p. 30; alUthaimin, 2004, pp. 333-338). Early Muslims and scholars went so far as to emphasize the practice's importance that 'Alī ibn al-Husayn is reported to have said, "The one who doesn't enjoin good and forbid evil is like the one who abandons the book of Allah" (Ibn Kathìr, 1990, p. 115).

Considering the holistic maqāssid lens illustrated above, one must keep in mind that Islamic ideals view the natural preservation of social order as a communal duty. Thus, every individual is responsible for maintaining order not

\footnotetext{
${ }^{2}$ Will be referred to throughout this article as 'al-amr wa al-nahy'.
} 
just for themselves, but also in their capacity to influence others to adhere to ethical conduct. This seriously violates modern individualistic societal ideals of one's personal freedom to choose unethical actions that are not considered illegal. The principle of al-amr wa al-nahy does not entail that Muslims must always take some form of action regardless of the setting or nature of their relationships. However, as it pertains to mental health clinicians, there is a significant distinction between the context of a patient's immoral behavior that is directly related to their psychological distress, as opposed to a behavior that is secondary, irrelevant, or unrelated to the presenting problem or diagnosis. In addition, given that the clinician-patient relationship is a fiduciary one contracted upon providing psychological treatment in exchange for a fee, the scope for al-amr wa al-nahy or any secondary or irrelevant aspects of the patients' life becomes of lesser relevance to the nature of the relationship. However, this does not eliminate a significant problem that arises when Muslim clinicians encounter patients pursuing Islamically sanctioned behaviors that are directly related to their presenting pathology.

Additionally, even in circumstances when it is of secondary concern, in the spirit of wishing well for their co-religionists, Muslim clinicians may also experience internal guilt in the sense of wondering whether their responsibility of al-amr wa al-nahy actually applies to their clinical practice and whether they are responsible for neglecting their personal religious responsibilities with such a client, as doing so would clearly constitute the professionally sanctioned imposition of personal values.

\section{Moral Principles}

The final important consideration to bear in mind when discussing value conflicts in clinical practice is the Islamic system of internal moral principles, sometimes termed fiqh al-bätin or the inner dimensions of ethics (Keshavarzi \& Ali, 2018a). In balancing the injunctions of "commanding the good and forbidding the evil," several moral principles must be kept in mind. First, the clinician must differentiate between viewing an action as sinful or immoral and judging the patient's character, for Islam prohibits such value evaluations despite external manifestations of sin (Usmani, 2001). Second, the clinician must not deal with their client in a manner that exudes a sense of moral superiority (takabbur); rather, they must consider their own flawed human state and recognize that they also commit sins that require admonishment (Usmani, 2001). Third, the therapist must be a well-wisher who possesses true genuine sincerity (ikhlāss) for the client's welfare. Fourth, the admonisher must believe that the offer of rectification will likely be well received and not further alienate the receiver from their religion (Al-'Asqalānī, 1986, p. 272). Islam values the agency of individuals to 
choose their faith, belief, and actions. Since mercy, empathy, and compassion are tremendously important in the Islamic system of morals, they are either shared or complementary to the principles of the mental health codes of conduct highlighted above.

Empathy, a particularly crucial qualities for successful clinician-patient relationships (Goldfried, Greenberg, \& Marmar, 1990; Coale, 1998), can be defined as

understanding a person from his or her frame of reference rather than one's own, so that one vicariously experiences the person's feelings, perceptions, and thoughts... In psychotherapy, the therapist's empathy for the client can be a path to the comprehension of the client's cognitions, affects, or behaviors. (VandenBos, 2013)

Moreover, research on motivational interviewing reveals that empathy is a precondition of therapeutic change and of the patient's willingness to accept feedback (Miller \& Rollnick, 2004). However, a study of Christian therapists has shown that such an empathetic connection is greatly hindered when the clients had no faith or were engaging in behaviors contrary to the clinician's belief system. Those clinicians found themselves inclined to challenge, instead of to empathize with, the client's behaviors (Morrison \& Borgen, 2010). A similar inclination may exist in the mind of the Muslim therapist to practice al-amr wa alnahy; however, no comparable studies have yet been conducted among Muslim clinicians.

Ibn Hazm (d. 1064), author of the renowned treatise Tawq al-Hamāma [The ring of the dove] portrayed lovers' experiences without differentiation between same- or hetero-sex lovers (Ibn Hazm, 1950). Despite his unwavering commitment to Islam's prohibition of homosexuality in the same treatise, he nevertheless empathized with lovers regardless of the direction their love took. In other words, he asserted that empathy and tolerance do not necessitate acceptance. Therefore, a religious clinician who rejects their client's homosexual or other sinful behavior can still express the highly needed empathy in the therapeutic relationship, given that empathy is not synonymous with agreement.

\section{Ethical Decision Making: Value Conflicts and Potential Resolutions}

Reflecting on the discussion presented above, the authors will now attempt to reexamine Hussain's case and propose some reconciliatory solutions for the relevant value conflicts. 


\section{Case Formulation}

Hussain's case poses several challenges that would pull an observant Muslim mental health clinician in different directions. Enumerated below are some of the ensuing conflicting thoughts:

- Respecting the client's autonomy.

- Offering competent services regardless of the client's background.

- Abiding by the professional and legal reports, declarations, and ordains declaring homosexuality a normal variation of human behavior and calling for a ban on treatments for homosexual individuals (Shear, 2015; Glassgold et al., 2009; The LPS Executive Committee, 2015).

- Empathizing with the client without indicating acceptance of the behavior.

- Referring the client to a clinician who might be willing to work with them.

- Valuing the centrality of the maqāsid, particularly preserving one's faith and lineage, and viewing the client's problems as compromising them.

- The obligation to practice al-amr wa al-nahy, at least by not affirming sins and wrongdoings.

- Utilizing their psychological expertise to assess a client's readiness to try changing their sexual orientation using various types of therapies. A clinician might see this in line with al-amr wa al-nahy by one's speech.

- Disclosing their personal values to excuse themselves in God's sight (without imposing them).

- Worrying about supporting a sinner/wrongdoer.

- Worrying about the legal consequences of refusing to work with a certain client population.

- Expressing unconditional positive regard and empathy.

- Manifesting the qualities of compassion and mercy.

\section{A. General Considerations}

Various ethical decision-making models can help clinicians understand and dissect ethical dilemmas, identify relevant codes of ethics, generate potential courses of action, consider the consequences of each action, and choose and implement a course of action (Kocet \& Herlihy, 2014; Forester-Miller \& Davis, 1995; Congress, 1999; Dolgoff, Loewenberg, \& Harrington, 2009; Reamer, 1995). In the process, they recommend a great deal of self-reflection and awareness, a good grasp of the codes of ethics, seeking the supervision of senior clinicians, and seeking personal counseling, all of which are critical to ascertaining the best course of action when caught in an ethical dilemma.

The practice of al-amr wa al-nahy and all forms of advising and teaching are, in general, engulfed within a fold of wisdom (Qur'an 16:125), which has also 
been considered critical for effective psychotherapy and multicultural competence in clinical practice (Hanna \& Ottens, 1995, as cited in Osterlund, 2014). In her qualitative study, Osterlund (2014) compiled the following holistic and interactive themes as constructs of wisdom in therapeutic relationships: reflective attitude, insight, emotional intelligence, cognitive ability, real-world skills, and concern for others. All of these constructs and qualities could enable clinicians to resolve ethical dilemmas more wisely.

\section{B. Ethical Bracketing}

Ethical bracketing (EB) has been proposed as a modality of addressing the value conflicts of religious clinicians when dealing with clients whose behaviors contravene those religious principles. According to Elliot, some ethicists recommended quitting the mental health profession if a clinician feels that they cannot bracket their values and abide by the professional guidelines. Others recommended practicing in settings that do not require professional licensing, meaning that they would not have to adhere to guidelines (Hermann \& Herlihy, 2006; Remley \& Herlihy, 2007, as cited in Elliott 2011).

Elliot then proposed her own perspective: the "both/and not either/or" approach. Like many others who wrote on the topic, she emphasized that mental health clinicians, just like any other citizens, have the right to hold personal beliefs and adhere to whatever values they wish. However, those who assume this role are expected to adhere to the profession's ethical guidelines. She encouraged clinicians to utilize a client-centered approach, in which they express unconditional positive empathy toward their clients/patients. Instead of projecting their own views or seeing "either" the clinicians "or" the client's realities as acceptable, clinicians are encouraged to accept "both" realities. In conclusion, Elliot argued that this approach will enable them to practice with "congruence and comfort," holding personal beliefs and values without imposing them on clients (Elliott, 2011).

Kocet and Herlihy (2014) suggested a similar approach, "Ethical bracketing," which they defined as

intentional separating of a counselor's personal values from his or her professional values or the intentional setting aside of the counselor's personal values in order to provide ethical and appropriate counseling to all clients, especially those whose worldviews, values, belief systems, and decisions differ significantly from those of the counselor. (p. 182) 
Both of these approaches are, in essence, very similar. But despite having gained wide acceptance among clinicians and mental health ethicists, they do not really encompass the dilemmas experienced by many religious clinicians. These approaches seem to postulate that values are just deeply held beliefs or preferences that have no practical ramifications. However, as highlighted above, Islamic principles such as al-amr wa al-nahy call for some form of action and mandate a level of social collectivistic responsibility. They also defy the very conception of "do no harm," as the religiously devout should, in essence, seek their clients' welfare in the afterlife perhaps even more than their welfare in this world.

In his advice, Al-Ruhāwī clearly invoked public interest and theology as the rationale behind not offering an abortion for a patient who demands it if a holistic assessment of harm and benefit warranted this refusal (Al-Ruhāwī, 1967, p. 109). For those values to remain unmanifested in one's actions or practice would seem like an unacceptable passivity for many religiously devout believers and does not solve the conflict. As Al-Rabae (2009) put it, "a professional counselor has an obligation to the code of ethics and as a Muslim has an obligation to the Islamic moral values and ethics" (p. 39).

This being said, perhaps a reconciliatory approach could entail a less optimal solution from an Islamic standpoint but still a compatible one built on the principle of the absence of capacity (qudra) to truly fulfill the highest ideals of alamr wa al-nahy. This may indeed be exercising the third level of al-amr wa alnahy, namely, holding one's beliefs and values in one's heart, given the professional ethical sanctions against expressing their concern about their client's immoral behavior. This ultimately amounts to the "both/and not either/or" approach and EB.

However, one must remember that the difference between a purely clientcentered approach is the fact that the clinician must still believe it to be sinful and unacceptable. Given that postmodernist theories such as client-centered therapy's conception of multiple relative truths are inconsistent with Islamic theology, to truly tackle the issue from an Islamically acceptable perspective one must construct a reconciliatory response that accords with the Islamic tradition and can be exercised faithfully by Muslim clinicians.

Another possible approach to EB could be to consider that empathy is not synonymous with agreement or affirmation. As mentioned in the section of alamr wa al-nahy, oftentimes the context in which clinicians see their patients may render any discussions of the morality of their decision making secondary to their psychological suffering, whereas a Muslim clinician is focused on alleviating the most central aspect of their suffering. In such cases, the client's presenting problem is not directly related to those conflicted ethical values, but rather is something that the clinician came to know about as a byproduct of a thorough 
psychological assessment, such as coming to know that a patient indulges in extramarital affairs, same-sex relationships, or social drinking. Although these are considered Islamically unethical, they might not be central to the client's suffering or complaint and thus beyond the practitioner's scope to discuss, given the fiduciary nature and context of the client-therapist relationship.

The power of being in a compassionate and empathic relationship with their therapist can contain incredible psychological healing capacities. Perhaps this is the most salient feature of the therapeutic alliance. Another consideration is that if a Muslim clinician is working with a Muslim patient, it is likely that they are already familiar with the Islamic religious injunctions surrounding their behavior. Thus, even if the therapist had the liberty to verbalize their disapproval or recommend compliance with Islamic ethics, it would likely have minimal efficacy in promoting such behavior (Miller \& Rollnick, 1991).

This was discussed above, for al-amr wa al-nahy may contravene clinical wisdom if engaging in this practice would likely do more harm than good, even when their "unethical" behavior is directly related to their psychological distress. If the patient is not a Muslim, Sunni theologians of the Ash 'ari school may render this responsibility as irrelevant due to the absence of a shared religious framework. Ash 'ari theologians view morality as a byproduct of that particular moral ontological framework (Bazdawī, 2011, p 214).

According to this view, therefore, non-Muslims cannot be held accountable for their actions because Islam's standards for good and evil are inapplicable to them, just as Muslims may tolerate the non-Muslims' drinking of alcohol. However, there may be less scope for this according to Māturīdī theologians who, given their belief in universal good and evil, maintain that the mandates of al-amr wa al-nahy may be applicable to non-Muslims, given that they would be held accountable (mukallaf) for moral violations that are knowable by the intellect alone (Ibn Abidin, Haskafi, \& Nasafi, 2006).

\section{The Collaborative Transparent Approach}

As part of the ethical bracketing framework, Kocet and Herlihy (2014) proposed that a more collaborative approach can be taken, namely, a joint clinician-client exploration of the potential value-based conflicts and their potential impact on the therapeutic relationship. Patterson (1989) seems to have shared a similar view when he wrote,

The Counselor or therapist should not impose his or her values on clients, but this does not mean that the therapist should refuse to discuss values, ethics, or philosophy. Nor does it mean that the therapist may not at times express his or her values. The therapist may do so at the request of the client. In addition, there may be times when the therapist thinks it is 
necessary or desirable for the client to be aware of these values, or times in which the client should know how the therapist stands on certain ethical or value issues. Being genuine or honest in the relationship sometimes means that the therapist should express his or her values. When therapists believe that the therapy relationship or process would be improved by explicitly acknowledging their values and beliefs, they can do so. Such values should be clearly labeled as their own (or possibly sometimes as society's in general). When values are openly expressed in this way, there is no coerciveness about them. (p. 167)

As this approach might indicate, therapists should feel free to discuss conflicts between Islamic ethical codes of conduct and the patient's current behavior while maintaining that direct theological counsel lies outside the scope of their relationship. Thus, spirituality can be a part of the therapeutic dialogue inasmuch as it is related to their client's psychological distress. If the client seems to need theological or pastoral counsel in conjunction with their mental health treatment, the clinician can provide a clerical referral, thereby acknowledging his or her lack of expertise in Islamic spirituality and theology.

This would be consistent with maintaining a genuine relationship with the client. It is plausible to assume that clients may, in fact, appreciate their clinician's genuine desire to be fully present and honest with them. The client has the complete agency to refuse the suggestion, which, in the authors' opinion, would not constitute "imposing values."

This approach largely depends on the clinician's wisdom and evaluation of the situation and thus must be utilized with the utmost carefulness, given the potential risks.

\section{Consenting to an Islamically Integrated Therapy Model}

According to the ACA code of ethics (2014), "A.2.a. Informed Consent: clients have the freedom to choose whether to enter into or remain in a counseling relationship and need adequate information about the counseling process and the counselor" (p. 4). Recently, a few centers established in the U.S. and the U.K. have adopted an Islamically integrated model of psychotherapy, such as Khalil Center and Ihsan Center, respectively. Clients seeking services in such centers are informed of and agree to utilize the models of therapy that integrate Islamic spirituality and values. In other words, they cater to the needs of religiously devout individuals seeking out clinicians who share and understand their religious values.

But can such informed consent be the basis for clinicians' engagement in certain spiritual and psychological interventions that would otherwise be 
inappropriate in other settings? This is a question worth investigating, of course while abiding by the professional code pertaining to "Treatment Modalities" that emphasizes using interventions that are grounded in theory and/or have a scientific foundation; explaining the risks, benefits and ethical considerations of any developing or innovative (non-standard) techniques; and avoiding intervention that are proven to be harmful (ACA, 2014, p. 10). This can be seen as combining the counselor's role with that of an imam/chaplain/religious guide, given the Islamically integrated nature of treatment. This specialty service may be designed to address specific service gaps. Such psychotherapies work within in a shared religious framework, meaning that the terms of the psychotherapeutic relationship can, at times, be built on a common moral platform set as the parameters of the counseling space. Significant data reveal that American Muslims seem to be drawn to such services, and providing Islamically integrated care may reduce barriers for service delivery (Amri \& Bemak, 2013; Killawi et al., 2014).

In Hussain's case, regardless of the reconciliatory approaches listed above, one must still consider if there is an actual or a perceived conflict between values and religious ethics. Hussain shows a degree of dissonance and incongruence, for he identifies with normative Sunni teachings' prohibition of homosexual acts and yet feels conflicted between this and his belief that his feelings are beyond his control and that God created him this way. In this instance, there does not seem to be a real value conflict, in that Hussain himself is conflicted. Thus, a competent clinician needs to help him create a space in which he can reconcile his religious beliefs and feelings. According to Islamic theology, people are not responsible for their feelings or impulses, but only for what they actually do. Therefore, working with Hussain might entail exploring how he can remain faithful while accepting the possibility that he may be predisposed to homosexuality.

The question still remains as to whether a client who voluntarily contacted a therapist in an effort to resist such an impulse would constitute reparative therapy, as this is completely banned by most ethics committees and some legislations. Although there is evidence that reparative therapy may not be effective (Glassgold et al., 2009), Muslim clinicians may still find clinically efficacious approaches to acknowledge homosexual desires and religious beliefs that do not entail a rejection of either but rather help clients find avenues to cope with, restrain, or redirect their sexual impulses. If this was also considered unethical, would this contradict those ethical principles that consider the imposition of values or discrimination as unethical, while mandating clinicians to refuse to work with clients that request such services?

\section{E. Legal Considerations}


As legal systems and professional guidelines vary from one place to the other, people who struggle with value conflicts and cannot abide by certain codes of ethics could possibly choose to work in different settings, capacities, or countries. Elliott (2011) reported that some ethicists have recommended this as a solution. She gave the example of working in settings that do not require professional licensing, which means that there are no guidelines to which one must adhere, such as non-profit organizations in the American state of Alabama.

In many Muslim countries, however, where Islamic law is a major source of legislation, professional ethics and legal systems take Islamic values into consideration. Therefore, Muslim clinicians have to be aware of the legal context within which they operate. As Allen (2012) put it, "legal obligations usually supersede professional ethics."

\section{Conclusion}

In conclusion, although both the Islamic and current secular systems of professional ethics share many ethical principles, significant fundamental differences do exist in terms of the foundational principles upon which they are constructed. Therefore, clinicians may find themselves at odds with the competing requirements of both sets of expectations and thus experience a conflict of values. As a result, their understanding of what constitutes ethical conduct and how to adhere to professional ethics without compromising one's values becomes unclear and confusing. Moreover, the unilateral handling of clinicians' value conflicts from either the professional ethical perspective or a religious perspective poses more challenges to reconciling the emerging dissonance and conflict (Okpara, 2017).

This paper presented several strategies to reconcile these potential conflicts and highlighted some significant differences that may continue to pose significant challenges in finding a bridge between the two systems. In particular, the individualistic and secular nature of Western psychology has apparently affected the development of Western professional ethics' disregard of the metaphysical, social, and public aspects of certain religious values and assume that these can simply be bracketed in order to maintain adherence to these secular codes of conduct. The solutions analyzed within this article provide the tools for managing such conflicts, although a true resolution would entail a deeper evaluation of the two viewpoints' epistemic origins and a more meaningful bridging. Alternatively, Muslims may need to construct their own ethical codes of conduct, codes that review, integrate, and adapt current professional ethical standards so that they are more consistent with a theistic ethical framework of practice. 
The current global awakening of the fields of Islamic psychology and mental health means that the time is ripe for such a rigorous investigation. Conversations in these matters should bring together ethicists, jurists, and mental health professionals. Despite recent developments in Islamic bioethics, that field seems to fall significantly short with respect to the concerns of Muslim mental health professionals and focus only on biomedical matters. Perhaps renewed efforts will be directed toward creating an ethical decision-making model for Muslim mental health clinicians. 
The Journal of Islamic Faith and Practice // Volume 2, Issue 2

\section{References}

American Counseling Association. (2005). ACA code of ethics. Alexandria, VA.

Abī Al-Dunyā, A. M. (1997). Kitāb al-Amr bi al-Ma 'rūf wa al-Nahy 'an alMunkar [The book of enjoining good and forbidding evil]. Madina, Saudi Arabia: Makatabt al-Ghuraba' al-Athariyya.

Al-'Asqalānī, A. H. (1986). Fatḥ al-Bārī Sharh Șaḥ̄h al-Bukhārī [Commentary on Șaḥị̣ al-Bukhārī]. Cairo, Egypt: Dar Al-Rayyan Publishing House.

Ali, B., \& Keshavarzi, H. (2016). Forensic psychology in Islamic jurisprudence. Oxford Encyclopedia of Islamic Bioethics. Oxford: Oxford University Press.

Al-Ghazālī, M. M. (1992). Al-Mustașfā fì 'Ilm al-Ușūl [The essentials of Islamic legal theory). Beirut, Lebanon: Dar al-Kutub al-'Ilmiyya.

Al-Ghazālī, M. M. (1993). Bidāyat al-Hidāya [The beginning of guidance]. Cairo, Egypt: Madboli Publishing House

Al-Krenawi, A. (2005). Mental health practice in Arab countries. Current Opinion in Psychiatry, 18(5), 560-564.

Allen, K. (2012). What Is an Ethical Dilemma? The New Social Worker. Retrieved from http://www.socialworker.com/feature-articles/ethicsarticles/What_Is_an_Ethical_Dilemma\%3F/

Al-Munajjid, M. S. (2013). Al-Daruriyyāt al-Khams fì Maqāṣid al-Sharī'a [The five necessities in the objectives of Islamic law]. Retrieved from https://almunajjid.com/8496

Al-Naysābūrī, M. H. (2005). Saḥīh Muslim. Riyadh, Saudi Arabia: Dar Tayba.

Al-Rabae, A. (2009). Muslim counselors and the Western code of ethics. The Journal of Psychological and Counseling Studies, 2(1), 1-56.

Al-Ruhāwī, I. A. (1967). Adab al-Ṭabīb [Ethics of the physician]. Iran: Research Institute for Islamic and Complementary Medicine.

Al-Taftāzān̄, A. H. (2000). Sharh al- 'Aqā 'id al-Nasafìya. [Explanation of the fundamentals of the Islamic creed by al-Nasafi] Karachi: Maktabat al-Bushra. 
The Journal of Islamic Faith and Practice // Volume 2, Issue 2

Al-Umar, N. S. (2017). Maqșūd al-Amr bi al-Ma 'rūf wa al-Nahy 'an al-Munkar [The objective of enjoining good and forbidding evil]. Retrieved from http://almoslim.net/node/274730

Al-Uthaymin, M. S. (2004). Sharh al-Arba inn al-Nawawīya [Explanation of the forty Nawawi hadiths]. Riyadh, Saudi Arabia: Dar al- Thurayya.

American Counseling Association (ACA). (2014). ACA code of ethics: As approved by the ACA Governing Council. American Counseling Association.

American Psychiatric Association (APA). (2013). Diagnostic and statistical manual of mental disorders (DSM-5®). American Psychiatric Pub.

American Psychological Association (APA). (2017). Ethical principles of psychologists and code of conduct. American Psychological Association.

Arnett, J. J. (2008). The neglected 95\%: Why American psychology needs to become less American. American Psychologist, 63(7), 602.

Amri, S., \& Bemak, F. (2013). Mental health help-seeking behaviors of Muslim immigrants in the United States: Overcoming social stigma and cultural mistrust. Journal of Muslim Mental Health, 7(1), 43-63.

Badri, M. (2018). The dilemma of Muslim psychologists. Malaysia: Islamic Book Trust.

Balkin, R. S., Watts, R. E., \& Ali, S. R. (2014). A conversation about the intersection of faith, sexual orientation, and gender: Jewish, Christian, and Muslim perspectives. Journal of Counseling \& Development, 92(2), 187-193.

Bazdawī, M. (2011). Ușūl al-Dīn [The principles of religion]. Cairo: Maktaba alAzhariyya lil-Turath.

Bint Abdur-Rahman, K. (2013). Ahkām al-Marị̄ al-Nafsī fì al-Fiqh al-Islāmī [Rulings of the mentally ill in Islamic jurisprudence]. Riyadh: Dar al-Somaie.

Burkholder, D., \& Hall, S. F. (2014). Ward v. Wilbanks: students respond. Journal of Counseling \& Development, 92(2), 232-240. 
Burkholder, D., Hall, S. F., \& Burkholder, J. (2014). Ward v. Wilbanks: Counselor educators respond. Counselor Education and Supervision, 53(4), 267-283.

Carlson, T. D., \& Erickson, M. J. (1999). Recapturing the person in the therapist: An exploration of personal values, commitments, and beliefs. Contemporary Family Therapy, 21(1), 57-76.

Chaleby, K S. (2001) Forensic psychiatry in Islamic jurisprudence. London: International Institute of Islamic Thought.

Coale, H. W. (1998). The vulnerable therapist: Practicing psychotherapy in an age of anxiety. Psychology Press.

Cole, M. (2006). Internationalism in psychology: We need it now more than ever. American Psychologist. 61(8), 904.

Congress, E. P. (2017). What social workers should know about ethics: Understanding and resolving practice dilemmas. Social Work Ethics, 1909.

Cook, M. (2001). Commanding right and forbidding wrong in Islamic thought. Cambridge: Cambridge University Press.

DeSantis, N. (December 11, 2012). Eastern Michigan U. settles counseling student's lawsuit for \$75,000. Chronicle of Higher Education. Retrieved from http://chronicle.com/blogs/ticker/jp

Dolgoff, R., Lowenberg, F. M., \& Harrington, D. (2009). Ethical decisions for social work practice (8th ed.). Belmont, CA: Brooks/Cole.

Elliott, G. R. (2011). When values and ethics conflict: The counselor's role and responsibility. Alabama Counseling Association Journal, 37(1), 39-45.

Fadel, H. E. (2013). Editorial. Encyclopedia of Islamic Medical Ethics: Part I. Amman, Jordan: Jordan Society for Islamic Medical Sciences.

Farook, S. (2008). Social responsibility for Islamic financial institutions: Laying down a framework. Journal of Islamic Economics, Banking and Finance, $4(1), 61-82$. 
Forester-Miller, H., \& Davis, T. E. (1995). A practitioner's guide to ethical decision making. Alexandria, VA: American Counseling Association.

Ghaly, M. (Ed.). (2016). Islamic perspectives on the principles of biomedical ethics. World Scientific Publishing.

Glassgold, J. M. et al. (2009). Appropriate therapeutic responses to sexual orientation. American Psychological Association

Goldfried, M. R., Greenberg, L. S., \& Marmar, C. (1990). Individual psychotherapy: Process and outcome. Annual Review of Psychology, 41(1), 659-688.

Grimm, D. W. (1994). Therapist spiritual and religious values in psychotherapy. Counseling and Values, 38(3), 154-164.

Hathaway, W. L., \& Ripley, J. S. (2009). Ethical concerns around spirituality and religion in clinical practice. In Spirituality and the therapeutic process: A comprehensive resource from intake to termination, 25-52.

Hourani, G. F. (2007). Reason and tradition in Islamic ethics. Cambridge: Cambridge University Press.

Ibn 'Abidin, M., Haskafi, M. A., \& Nasafi, M. (2006). Sharḥu sharh al-manār. Karachi: Idaratal Quran.

Ibn Hazm, A. A. (1950). Tawq al-Hamāma fì al-Ulfa wa al-Ullāf [The ring of the dove: About love and lovers]. Cairo: Hijazi Publishing House.

Ibn Kathīr, I. O. (1990). Al-Bidāya wa al-Nihāya (The beginning and the end) (Vol. 9). Beirut: Maktabat al-Ma'arif.

Ibn Taymiyya, A. A. (1983). Al-Amr bi al-Ma'rüf wa al-Nahy 'an al-Munkar [Enjoining Good and Forbidding Evil]. Jeddah : Dar al-Mujtama' li al-Nashr wa al-Tawzi'.

Izadi, A. R., Ebrazeh, A., Drikvand, J., \& Pouladchang, M. (2014). Hospital employees' knowledge of enjoining good and forbidding evil. Health Spiritual Med Ethics, 1(2), 12-9.

Kamali, M. H. (2011). Law and ethics in Islam: The role of the maqāșid. In K. Vogt, L. Larsen, \& C. Moe (Eds.). New directions in Islamic thought: 
Exploring reform and Muslim tradition (pp. 23-46). New York, NY: I.B. Tauris.

Kasapovic, S. (2018). Islamic tradition meets modern social science: The case of "Islamic psychology" (Unpublished master's dissertation). Hamad Bin Khalifa University, Qatar.

Keeton v. Anderson-Wiley, No. 1:10-CV-00099-JRH-WLB, 733 F. Supp. 2d 1368 (S. D. Ga., Aug. 20, 2010). Retrieved from https://cases.justia.com/federal/districtcourts/georgia/gasdce/1:2010cv00099/51293/48/0.pdf?ts=1282381292

Keshavarzi, H., \& Ali, B. (2018a). Islamic perspectives on psychological and spiritual well-being and treatment. In H. S. Moffic, J. Peteet, A. Hankir, \& R. Awaad (Eds.), Islamophobia \& psychiatry: Recognition, prevention, and treatment. New York, NY: Springer International (In Press).

Keshavarzi, H. \& Ali, B. (2018b). Exploring the role of mental status \& expert testimony in the Islamic Judicial process. In A. Padela (Ed.), Doctors \& jurists in dialogue: Constructing the field of Islamic bioethics. Notre Dame, IN: University of Notre Dame Press (In Press).

Killawi, A., Daneshpour, M., Elmi, A., Dadras, I., \& Hamid, H. (2014). Recommendations for promoting healthy marriages \& preventing divorce in the American Muslim community. http://www.ispu.org/pdfs/ISPU_Promoting_Healthy Marriages_and_Preventing_Divorce_in_the_American_Muslim_Community. pdf

Kim, U. (2000). Indigenous, cultural, and cross-cultural psychology: A theoretical, conceptual, and epistemological analysis. Asian Journal of Social Psychology, 3(3), 265-287.

Kocet, M. M., \& Herlihy, B. J. (2014). Addressing value-based conflicts within the counseling relationship: A decision-making model. Journal of Counseling \& Development, 92(2), 180-186.

Lopes de Jesus, L. (2016). An exploration of the experiences of religiously committed counselling professionals working with religious and non-religious client (Doctoral dissertation, University of Roehampton). Retrieved from EThOS (uk.bl.ethos.690104). 
The Journal of Islamic Faith and Practice // Volume 2, Issue 2

Martz, E., \& Kaplan, D. (2014). New responsibilities when making referrals. Retrieved from: https://www.counseling.org/docs/defaultsource/ethics/ethics_ocober-2014.pdf

Miller, W.R., \& Rollnick, S. (1991). Motivational interviewing: Preparing people to change addictive behavior. New York: Guilford Press, 1991.

Miller, W. R., \& Rollnick, S. (2004). Talking oneself into change: Motivational interviewing, stages of change, and therapeutic process. Journal of Cognitive Psychotherapy, 18(4), 299.

Morrison, M., \& Borgen, W. A. (2010). How Christian spiritual and religious beliefs help and hinder counselors' empathy toward clients. Counseling and Values, 55(1), 25-45.

Okasha, A., Karam, E., \& Okasha, T. (2012). Mental health services in the Arab world. World Psychiatry, 11(1), 52-54.

Okpara, T. (2017). Religious Beliefs and Counseling Ethical Guidelines: Challenges for Catholic Counselors (Doctoral dissertation, Walden University). Retrieved from ProQuest (10602715).

Osterlund, L. C. (2014). Wisdom in the counseling relationship. Jesuit Higher Education: A Journal, 3(2), 11.)

Padela, A. I. (2007). Islamic medical ethics: A primer. Bioethics, 21(3), 169-178.

Patel, C. J., \& Shikongo, A. E. (2006). Handling spirituality/religion in professional training: Experiences of a sample of Muslim psychology students. Journal of Religion and Health, 45(1), 93.

Patterson, C. H. (1989). Values in counseling and psychotherapy. Counseling and Values, 33(3), 164-176.

Ragab, A. (2015). The medieval Islamic hospital: Medicine, religion, and charity. Cambridge University Press.

Ramadan, T. (2018). Islamic ethics: A very short introduction. Oxford University Press. 
Reamer, F. G. (2013). Social work values and ethics. New York: Columbia University Press.

Remley, T. P., \& Herlihy, B. (2010). Ethical, legal, and professional issues in counseling (3rd ed.). Upper Saddle River, NJ: Pearson.

Roccas, S. (2005). Religion and value systems. Journal of Social Issues, 61(4), 747-759:

Rudow, H. (2013, January 9). Resolution of EMU case confirms ACA Code of Ethics, counseling profession's stance against client discrimination. Counseling Today. Retrieved from https://ct.counseling.org/2013/01/resolution-of-emu-case-confirms-aca-codeof-ethics-counseling-professions-stance-against-client-discrimination/

Rutherford, B. K. (2006). What do Egypt's Islamists want? Moderate Islam and the rise of Islamic constitutionalism. The Middle East Journal, 60(4), 707731.

Sachedina, A. (2009). Islamic biomedical ethics: Principles and application. Oxford: Oxford University Press.

Scott, A. (2011). An exploration of the counsellor's experience of integrating Christian faith with clinical practice. (Doctoral dissertation, University of Manchester). Retrieved from EThOS (uk.bl.ethos.554146).

Shallcross, L. (2010). Putting clients ahead of personal values. Counseling Today, $53,32-34$.

Shear M. D. (2015, April 8). Obama calls for end to "conversion" therapies for gay and transgender youth. The New York Times. Retrieved from http://www.nytimes.com

Stewart, C. (2009). The inevitable conflict between religious and social work values. Journal of Religion \& Spirituality in Social Work: Social Thought, 28(1-2), 35-47.

Sue, S. (1999). Science, ethnicity, and bias: Where have we gone wrong? American Psychologist, 54(12), 1070.

The Lebanese Psychiatric Society (LPS) Executive Committee. (2015). Statement from the Lebanese Psychiatric Society. Retreived from 
The Journal of Islamic Faith and Practice // Volume 2, Issue 2

https://static1.squarespace.com/static/52567f12e4b02768cf839a59/t/567bd7c8 a128e603ba937910/1450956744013/LPS+homosexuality++ revised +2015 .pdf

Usmani, M. T. (2001). Spiritual discourses. Karachi, Pakistan: Darul Ishat.

VandenBos, G. R. (2013). APA dictionary of clinical psychology. American Psychological Association. 